\title{
EASTERN FOX SQUIRREL (SCIURUS NIGER): NEW THREAT TO PECAN ORCHARDS IN FAR WEST TEXAS
}

\author{
Jennifer K. Frey ${ }^{1}$, Jaime Iglesias ${ }^{2}$, and Krysta Herman ${ }^{3}$
}

\begin{abstract}
Aвstract.-We report the first records of the eastern fox squirrel (Sciurus niger) in Trans-Pecos Texas. Sciurus niger is widely established in pecan orchards in the Lower El Paso Valley of the Rio Grande, El Paso County. Expansion of this population to other pecan-growing regions along the Rio Grande in New Mexico is possible. Research is needed on both the extent of damage caused by S. niger to pecan production and the control methods in this situation. We recommend a goal of complete eradication of S. niger from this region. Sciurus niger should be delisted as a game species in El Paso County, Texas, and throughout New Mexico, where there are no native populations of the species.
\end{abstract}

RESUMEN.-Estamos reportando los primeros records de la prescencia de la ardilla eastern fox (Sciurus niger) en el area de Trans-Pecos Texas. Sciurus niger se encuentra ampliamente establecida en las huertas de nogal en el Valle Bajo del Rio Grande en el Condado de El Paso, Texas. La expansion de esta población de S. niger es posible a otras regiones productoras de nogal a lo largo de el Rio Grande en el estado de Nuevo Mexico. Es necesario investigar la extensión de el daño causado por $S$. niger en la producción de nogal, asi como tambien los posibles métodos de control. Recomendamos como meta final la completa erradicación de S. niger de esta región. Sciurus niger debe ser eliminada de la lista de especies de caza en el condado de El Paso, Texas, y a lo largo de el Estado de Nuevo Mexico donde no existen poblaciones nativas de esta especie.

The native geographic range of the eastern fox squirrel (Sciurus niger) is primarily associated with deciduous and pine-oak forests in the eastern United States (Hall 1981, Koprowski 1994). Additionally, the range of S. niger has been expanding westward across the Great Plains along rivers that have recently developed riparian forests (Koprowski 1994, Geluso 2004). However, S. niger also has been introduced to numerous locations west of its native range (Palmer et al. 2007). Although S. niger is considered a game species throughout much of its native range, most of the introductions have been within small towns and urban areas, presumably by people that have an appreciation for the species' diurnal and charismatic character (e.g., Frey and Campbell 1997). Populations of $S$. niger can thrive in urban situations because of the availability and diversity of ornamental trees, particularly those that provide winter-storable foods such as hard mast (e.g., oaks [Quercus], walnuts [Juglans], hickories $[$ Carya]) and cones of pines (Pinus; Frey and Campbell 1997, Koprowski 1994).

In the Southwest, the westernmost extent of the natural range of $S$. niger is the lower
Pecos River (Crockett, Terrell, and Valverde counties, Texas) and along the Rio Grande below the confluence of the Pecos River (Bailey 1905). Introduced populations also are present in the Pecos River watershed and on the Llano Estacado in New Mexico (Frey and Campbell 1997; Fig. 1). There have been no records of $S$. niger in Trans-Pecos Texas or anywhere within the Rio Grande basin above the confluence of the Pecos River, including in New Mexico. Herein, we report the first records of S. niger from the Rio Grande in Trans-Pecos Texas.

We first became aware of the presence of S. niger in pecan (Carya illinoinensis) orchards in the floodplain of the Rio Grande in El Paso County, Texas, in June 2011. We verified the occurrence with 2 male specimens collected 26 September 2011 from the Charlie Ivey Farm and deposited in the Vertebrate Wildlife Museum at New Mexico State University. Based on condition of the sutures in the skull and wear to the molars, both specimens were determined to be juveniles. Standard external measurements $(\mathrm{mm})$ including total length, tail length, hindfoot length, and ear length were 443-211-65-28 and 442-210-68-28. Mass

\footnotetext{
${ }^{1}$ New Mexico State University, Department of Fish, Wildlife and Conservation Ecology, Box 30003, MSC 4901, Las Cruces, NM 88003-8003. E-mail: jfrey@nmsu.edu

${ }^{2}$ Texas A\&M Agrilife Extension Service, El Paso County Extension, 9521 Socorro Rd., El Paso, TX 79927.

${ }^{3}$ New Mexico State University, Department of Plant and Environmental Sciences, Box 30003, MSC 4901, Las Cruces, NM $88003-8003$.
} 


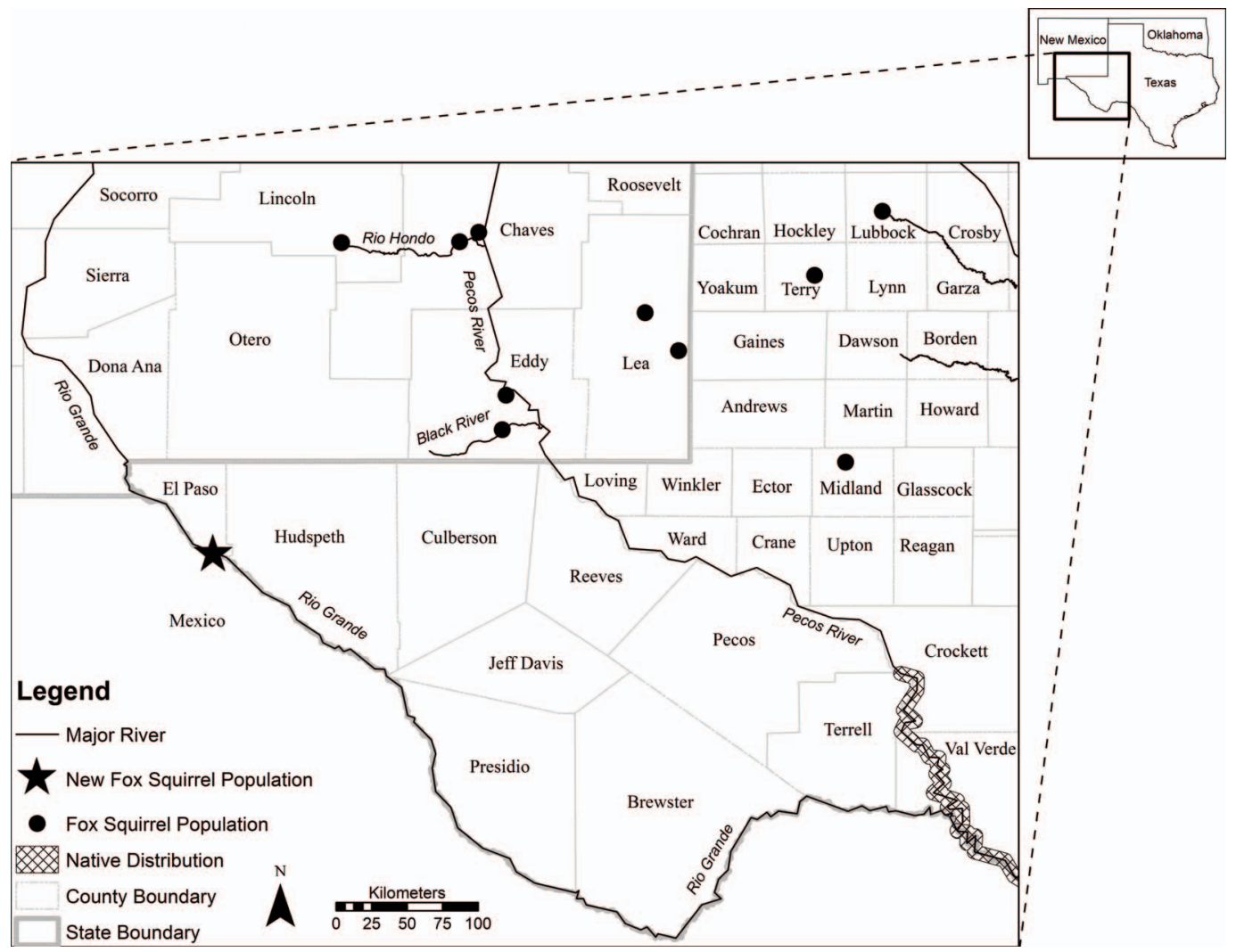

Fig. 1. Map of the native distribution (cross-hatching) and introduced populations (dots) of the eastern fox squirrel (Sciurus niger) in southwestern Texas and southeastern New Mexico. The new introduced population in the valley of the Rio Grande, El Paso County, Texas, is indicated with a star.

and testes size could not be determined because the specimens were eviscerated in the field. Subsequently, we confirmed presence of $S$. niger from a total of 6 pecan orchards throughout much of the Lower El Paso Valley, including near Socorro (C.P. Brown Farm, $\left.31.643253^{\circ} \mathrm{N}, 106.269536^{\circ} \mathrm{W}\right)$; near Morning Glory (Kevin Ivey Farm, $31.555228^{\circ} \mathrm{N}$, $106.203186^{\circ} \mathrm{W}$; Dr. Tarango Farm, 31.558619 ${ }^{\circ} \mathrm{N}, 106.188414^{\circ} \mathrm{W}$; MBM Farm, $31.554125^{\circ} \mathrm{N}$, 106.186428 ${ }^{\circ} \mathrm{W}$ ), near Fabens (Richard Bills Farm $31.520306^{\circ} \mathrm{N} 106.176258^{\circ} \mathrm{W}$ ), and south of Tornillo (Charlie Ivey Farm, $31.425097^{\circ} \mathrm{N}$, $106.0857^{\circ} \mathrm{W}$; $5 \mathrm{R}$ Enterprises, $31.416903^{\circ} \mathrm{N}$, $\left.106.070836^{\circ} \mathrm{W}\right)$. The rock squirrel (Spermophilus variegatus), which is native to the region and similar in external morphology to $S$. niger (Hall 1981), has long been a source of concern and a target for control efforts by pecan farmers in the region. Thus, presence of a new species, $S$. niger, was not recognized as it was commonly thought to be a different color morph with different habitat preference. Consequently, it is not known when S. niger first appeared in the Lower El Paso Valley. One pecan farmer reported that "the new type of squirrel” (i.e., S. niger) was present at least 6 years ago and perhaps $8-10$ years ago (C. Ivey, personal communication).

Pecans are not native to the Rio Grande (Toole 1965). Large-scale irrigated-orchard production of pecans in the region began in the 1930s in the Mesilla Valley, Dona Ana County, New Mexico, and shortly thereafter spread to the adjacent Lower El Paso Valley in Texas (Herrera 2000, Lillywhite et al. 2007). The Dona Ana-El Paso county region is now a leader in both quantity and value of pecans produced in the world (Herrera 2000). Thus, presence of $S$. niger is a source of concern for farmers in the region due to real and perceived losses to pecan production. 
In order to better understand the scope of the problem, during late winter 2012 we visited a pecan orchard at MBM Farms where problems with $S$. niger had been reported. This orchard was planted in the early 1960s and is one of the oldest pecan orchards in the Lower El Paso Valley. MBM Farms has several farming sections totaling 443 ha in the vicinity of Fabens, Texas. We examined an orchard that was perceived to have high levels of damage by S. niger; the orchard consisted of 12 ha with 827 pecan trees spaced every $12.2 \mathrm{~m}$. Although the density of $S$. niger in the orchard is unknown, these squirrels appeared to be abundant and were commonly observed. On 4 randomly selected plots totaling 271 trees, we visually searched for dreys (i.e., squirrel leaf nests) and tree cavities by walking down rows and carefully examining the trees. Leaf nests were mostly constructed in "crow's feet," which are situations where several new branches grow upward from limbs that were pruned to increase solar exposure to the tree crown. Leaf nests were observed in $12.9 \%$ of trees, with $54.3 \%$ of those trees having $>1$ leaf nest. In addition, $5.9 \%$ of the trees had cavities that could potentially be used for nesting. Sciurus niger may use multiple nests during a year, and hence, the number of nests counted is not a direct index of density (Koprowski 1994).

Under current situations, nest sites are not likely to be limiting due to the large number of crow's feet in each tree. However, given the limited diversity of food in these monotypic orchards, food availability could be a limiting factor during certain times of the year. For instance, food availability can be limiting in winter after stored nut reserves are used, or in summer prior to nut maturity (Koprowski 1994). We observed a high incidence of limbs that had been stripped of bark (both fresh and old scars) by squirrels. Although squirrels may strip bark for a variety of reasons including male scent-marking (Koprowski 1991), other studies have found bark (or underlying sap) of other tree species to be important sources of food, especially during times of food scarcity (Montgomery and Matlack 2010). Barkstripping by squirrels can kill branches; cause wounds that allow insects, fungi, and other pathogens to attack the tree; and, in extreme situations, kill trees (Mountford 1997). Farmers in the Lower El Paso Valley perceive bark-stripping as an important threat reducing pecan production, though its actual impact remains unknown.

Research is needed to determine the extent and nature of damage caused by S. niger to pecan orchards in El Paso County and to determine the means to control S. niger in these intensive agricultural situations. Studies in native pecan groves found that wildlife damage to pecans exceeded harvested pecans and that $S$. niger caused damage to nuts ranging from 17 to $67 \mathrm{~kg} \cdot \mathrm{ha}^{-1}$, which did not include losses due to caching or damaged limbs (Huggins 1991). Thus, S. niger may represent a significant source of economic loss to pecan producers in El Paso County.

We recommend that the management goal for S. niger in El Paso County be eradication, given the economic importance of pecan production in the Rio Grande region, and given that the population, thus far, appears restricted to the Lower El Paso Valley. However, natural or human-mediated expansion of S. niger to adjacent areas is possible, including expansion to the important pecan-growing region in the Hatch and Mesilla valleys in Dona Ana County, New Mexico. Distribution of $S$. niger can be monitored by use of artificial nest boxes or hair tubes, which can provide earlywarning surveillance for arrival of the species into new areas (Palmer et al. 2007). Currently, the only method of control used in El Paso County that we are aware of is shooting. However, it is unlikely that hunting can provide adequate control on its own (Koprowski 1994, Palmer et al. 2007). Rodenticide-treated bait stations used to control the rock squirrel (Spermophilus variegatus) along adjacent irrigation ditches likely have negligible impact on $S$. niger, which is associated with trees. Further, though several toxicants are EPA registered for controlling Spermophilus, none is registered for use on tree squirrels (Sciurus). Both Texas and New Mexico regard S. niger as a regulated game species. In order to improve flexibility of management options, especially use of lethal control methods, S. niger should be delisted as a game species in El Paso County, Texas, and throughout New Mexico, where there are no native populations of the species. Control methods should focus on killtrapping combined with exclusion from trees by use of metal collars and exclusion of orchards from potential colonization corridors 
(e.g., power lines, ornamental trees) by habitat modification or fencing (Jackson 1994). Recently developed automatic-reset kill traps (e.g., Goodnature Company, Wellington, New Zealand) have advantages over more conventional single-capture traps (e.g., choker-type box trap, Kania or Fenn spring trap, Conibear 110 body-gripping trap) and may offer a particularly effective solution. In addition, pecan trees should be pruned in ways to reduce growth of crow's feet, which provide good protection for $S$. niger. Research is needed to evaluate the efficacy of these methods in El Paso County pecan orchards.

We thank pecan growers in El Paso County for providing observations of eastern fox squirrels. We thank students in the 2011 Wildlife Damage Management class at New Mexico State University for reviewing methods to control fox squirrels and rock squirrels in pecan orchards.

\section{Literature Cited}

Bailey, V. 1905. Biological survey of Texas. North American Fauna 25:1-222.

Frey, J.K., AND M.L. CAMPBELL. 1997. Introduced populations of fox squirrel (Sciurus niger) in the TransPecos and Llano Estacado regions of New Mexico and Texas. Southwestern Naturalist 42:356-358.

Geluso, K. 2004. Westward expansion of the eastern fox squirrel (Sciurus niger) in northeastern New Mexico and southeastern Colorado. Southwestern Naturalist 49:111-116.

HaLl, E.R. 1981. The mammals of North America. 2nd edition. John Wiley \& Sons, New York, NY.

Herrera, E. 2000. Historical background of pecan plantings in the western region. College of Agriculture and Home Economics, New Mexico State University Guide H-626.
HugGins, J.G. 1991. Measuring wildlife depredation of native pecans. Proceedings of the Annual Conference, Southeastern Association of Fish and Wildlife Agencies 45:148-155.

JaCkson, J.J. 1994. Tree squirrels. Pages B171-B175 in S.E. Hygnstrom, R.M. Timm, and G.E. Larson, editors, The handbook: prevention and control of wildlife damage. University of Nebraska-Lincoln. 2 volumes.

Koprowski, J.L. 1991. Damage due to scent marking by eastern gray and fox squirrels. Pages 101-105 in S.E. Hygnstrom, R.M. Case, and R.J. Johnson, editors, Proceedings of the 10th Great Plains Wildlife Damage Conference. University of Nebraska, Lincoln, NE.

1994. Sciurus niger. Mammalian Species 479:1-9.

Lillywhite, J.M., T.L. Crawford, J. Libbin, and J. Peach. 2007. New Mexico's pecan industry: estimated impacts on the state's economy. New Mexico State University Agricultural Experiment Station Bulletin 791:1-8

Montgomery, D.K., and R.S. Matlack. 2010. Early winter feeding on elm bark by eastern fox squirrels near the western range terminus. Prairie Naturalist 42:71-72.

MountForD, E.P. 1997. A decade of grey squirrel barkstripping damage to beech in Laky Park Wood, UK. Forestry 70:17-29.

Palmer, G.H., J.L. Koprowski, and T. Pernas. 2007. Tree squirrels as invasive species: conservation and management implications. Pages 273-282 in G.W. Witmer, W.C. Pitt, and K.A. Fagerstone, editors, Managing vertebrate invasive species: proceedings of an international symposium. USDA/APHIS/WS, National Wildlife Research Center, Fort Collins, CO.

Toole, E.R. 1965. Pecan (Carya illinoensis (Wangenh.) K. Koch). Pages 121-123 in H.A. Fowells, compiler, Silvics of forest trees of the United States. Agriculture Handbook 271, U.S. Department of Agriculture, Washington, DC.

Received 5 December 2012 Accepted 3 May 2013 